\section{LACE-WING FLIES.}

THE latest number of the Arxivs de l'Institut de Ciencies, published at Barcelona, contains an excellent monograph of the Chrysopidæ of Europe from the pen of Father R. P. L. Navàs, the wellknown authority on the order Neuroptera. The present group, sometimes known as Hemerobiidæ, and in this country as "lace-wing flies," or "goldeneyes," presents many features of interest. From the point of view of economic entomology its importance rests on the fact that in the larval stage it is a great destroyer of aphids. Unlike the almost stationary larvæ of the Syrphids, or hawkflies, which are also of much value as devourers of plant-lice, the Chrysopid larva is able to move actively about from place to place in search of its prey. In this it resembles the larva of the ladybird, another great ally of the agriculturist against the same enemy.

The Chrysopid in its perfect state is a beautiful object; the fresh green colour of its body, which is also prolonged into the delicate tracery of its wings, and the large lateral compound eye-masses, which shine during life like burnished gold, give it an attractive appearance. This, however, is scarcely borne out by its behaviour, for it is capable when crushed or otherwise injured of emitting a most disgusting odour. The latter property may perhaps serve in some degree as a protection to the insect, a suggestion that seems to be favoured by its feeble and fluttering mode of flight. The ova are curious structures, being fastened in groups to the surface of a leaf by means of slender footstalks, thus, as Fr. Navàs points out, resembling a growth of minute fungi.

The present treatise, which is well illustrated, gives a full description of all the European Chrysopids, with a complete bibliography and a key for the diagnosis of the various species.

\section{THE POSITION OF SCIENCE.}

Memorial from the Imperial College.

THE following memorial, presented by the Right Hon. Arthur H. D. Acland, chairman of the Executive Committee, and Sir Alfred Keogh, rector (now acting as Director-General of the Army Medical Service) of the Imperial College, and by Sir John Wolfe-Barry, chairman of the delegacy of the City and Guilds (Engineering) College, has been forwarded to Lord Crewe, chairman of the governors of the college :-

"To the Marquess of Crewe, K.G., Lord President of the Council, Chairman of the Governors of the Imperial College.

"We, the undersigned, desire to support the Memorandum on the neglect of science in this country which was signed by thirty-six eminent men of science (including four former professors of this College), and published on February 2 last; and as the Imperial College is directed by its charter to oncentrate itself on 'Science in its application to Industry and to give the highest specialised instruction and provide the fullest equipment for the most advanced training and research' in various branches of science, we think it right to call your Lordship's attention to the extreme importance of this question at the present crisis in our national history.

"In the Memorandum it is truly said that "This grave defect in our national organisation is no new thing. ... In the year 1887 Prof. Huxley, who was for fifteen years Professor and Dean of the Royal College of Science and Royal School of Mines, which are now with the City and Guilds (Engineering) ColNo. 2417 , vOL. 96] lege integral parts of the Imperial College, said:'Everybody. . . here is aware that at this present moment there is hardly a branch of trade or of commerce which does not depend, more or less directly, upon some department or other of physical science, which does not involve, for its successful pursuit, reasoning from scientific data.' This statement remains as true now as when it was made.

"We do not wish to take up your time by asking you to see us personally, but we consider it to be our duty to let you know as our Chairman that we cordially support the views of the signatories to the Memorandum, and sincerely hope that in a matter so vital to the welfare of the country remedial measures may be adopted."

The memorial is signed by the following professors, chairs being given in brackets :-H. B. Baker (Chemistry); V. H. Blackman (Plant Physiology); W. A. Bone (Chemical Technology-Fuel and Refractory Materials); H. L. Callendar (Physics); H. C. H. Carpenter (Metallurgy); C. Gilbert Cullis (Economic Mineralogy); W. E. Dalby (Mechanical and Motive Power Engineering); Stephen M. Dixon (Civil Engineering); J. Bretland Farmer (Botany); A. R. Forsyth (Mathematics); A. Fowler (Astrophysics); Wm. Frecheville (Mining); Percy Groom (Technology of Woods and Fibres); E. W. MacBride (Zoology); T. Mather (Electrical Engineering); J. C. Philip (Physical Chemistry); H. G. Plimmer (Comparative Pathology); R. J. Strutt (Physics); Jocelyn Thorpe (Organic Chemistry); A. N. Whitehead (Applied Mathematics); W. Watson (Physics); and W. W. Watts (Geology).

\section{SCIENCE AND GOVERNMENT.}

PROF. E. B. POULTON, in delivering the third Galton lecture before the Eugenics Education Society on February 16, said that the justification of the society lies in the fact that man, acting in a community, cannot help letting loose the forces that "improve or impair the racial qualities of future generations either physically or mentally." When these forces are tremendous, as in war, immense future effects must follow. The victory of Germany would impose upon mankind a new criterion, leading to the predominance of a revolting type. But every law, custom, or tradition by which society helps or restrains any of its individual members has some effect for the good or for the evil of future generations. Society is influenced by the tradition that marriage between first cousins is injurious. In consequence of this tradition such marriages are less frequent than they would otherwise be. There is no evidence that the tradition is well founded, and, in July, 1870, Charles Darwin wrote to Sir John Lubbock, pointing out that it was "manifestly desirable that the belief should either be proved false, or should be confirmed," and suggesting that the proper queries should be inserted in the forthcoming census. When the Bill was considered in committee, Lubbock moved to insert the words, "whether married to a first cousin," but the motion was opposed for all sorts of frivolous reasons, and finally rejected by 92 votes to 45 . The neglect of eugenics by the Government has been as conspicuous as its neglect of other branches of science. The next general election will reveal a revolution in the political thought of the country, and the urgent necessity for the society will be to fight alongside the other sciences and the great business interests of the country, ensuring that scientific men and business men shall have weight in our future form of Government. When the war.came the late Prof. Meldola, with his unrivalled knowledge of the relations between science 